\title{
Update for Examination Sheet of International Standards for Neurological Classification of Spinal Cord Injury
}

\author{
Berrin GÜNDÜZ, Belgin ERHAN \\ Istanbul Physical Medicine and Rehabilitation Training Hospital, Istanbul, Turkey
}

The International Standards for Neurological Classification of Spinal Cord Injury (ISNCSCI) were developed by the American Spinal Injury Association (ASIA) to be used for the evaluation of patients with spinal cord injury, and they have been revised several times to date. The aim of these standards is to provide precision in defining the level and the severity of the injury and to provide research and patient care centers in defining the lesion reliable data for (1).

The studies conducted to develop a standard evaluation method began in the late 1960s; ISNCSCI is the most commonly accepted and used method. The first development of these standards began with ASIA issuing a standard system for the National Spinal Cord Injury Statistical Centre in 1982; important revisions were made in 1989 and 1992. The Frankl rating system, which was benefited in its preparation, was redefined and was named the ASIA Impairment Scale, and the examination methods have been defined in detail $(2,3)$. This revision was approved which is formerly known as International Medical Society of Paraplegia International Spinal Cord Society (ISCOS). Subsequently, the standards were revised again in 1996, 2000, and 2011, and any problems that had surfaced during the time the standards were used were clarified $(3,4)$.
In the last revision conducted in 2011, a few changes were made, and use of the standards was facilitated by updating the pictures in the evaluation form. Although it is suggested that most cases can be classified using these standards, it is also emphasized that sometimes there may be problems $(3,4)$. This evaluation form was previously translated into Turkish and published with the permission of ASIA $(5,6)$. The evaluation form was then updated in 2013, and some additions and revisions were made (7). The aim of this scientific letter was to share the current evaluation form that was translated into Turkish with the permission of ASIA (Appendix 1) and to explain the revisions made.

The first changes that were noticed among the revisions in the examination form were the location of the Figure representing the body dermatomes, which was moved to the middle of the front page, and the division of the examination page as right and left. Motor examiner levels were aligned with sensory levels. In the Turkish abbreviation, "Ğ" was used for sağ (right) and " $\mathrm{L}$ " was used for sol (left).

Some revisions in the logo and titles were made; the ISCoS logo was added to both pages and a signature was added for the examiner. The size of the boxes to be filled for scoring of the motor and sensorial evaluation was enlarged.

Address for Correspondence: Dr. Berrin Gündüz, İstanbul Fizik Tedavi Rehabilitasyon Eğitim ve Araştırma Hastanesi, İstanbul, Türkiye. Phone: +90212442 2200 E-mail: gunduzberrin@gmail.com

Received: July 2014 Accepted: August 2014

(OCopyright 2015 by Turkish Society of Physical Medicine and Rehabilitation - Available online at www.ftrdergisi.com 


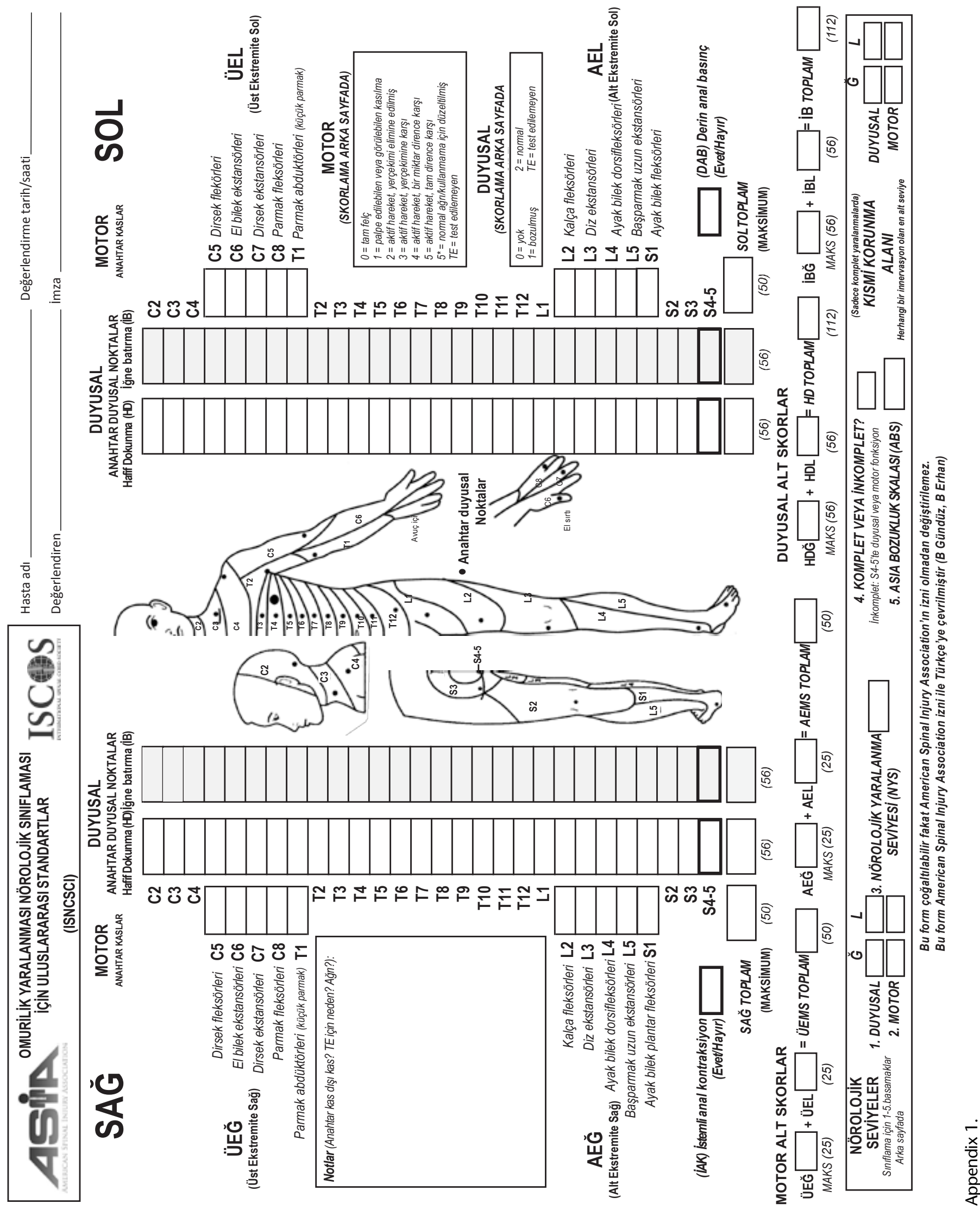



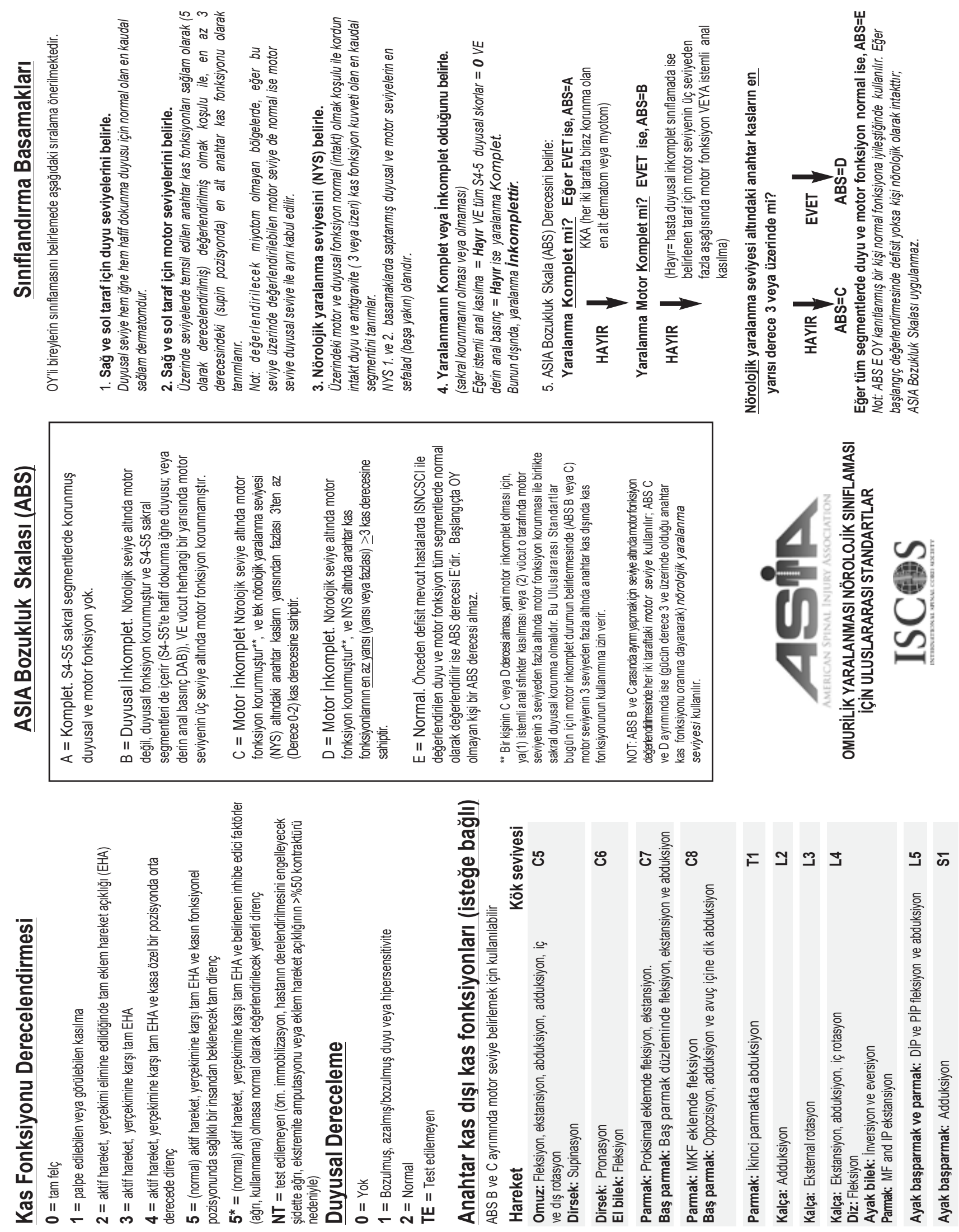
The boxes for evaluations about sacral sparing (voluntary anal contraction and deep anal pressure) were moved to S4-S5 dermatome level, and the frames of the boxes were thickened and made more explicit. Moreover, $10 \%$ shading was added to the boxes for pin prick sensation to easily differentiate.

In the abbreviations for the score and subscores, first the evaluated function and then the right or left side were specified.

In the bottom of the front page the 'Single Neurologic Level' was replaced with 'Neurological Injury Level'. The numbering of neurological levels on the front page corresponds to the classification steps on the back page.

The definition of the Neurological Injury Level on the back page of the form was clarified. Non-key muscle functions, were added on the back page and their levels were specified. Non key muscles, may be used in the differentiation of $A B S B$ and $C$ as indicated previously. The purpose of adding non key muscles was to form a common language. Many reference books in determining root levels of these muscles. Upper myotomes were used preferred in the cases in which different myotomes were indicated for muscle function in different sources. The reason for evaluations made with muscle functions, but not with the muscle names, were to lead to less confusion. It is not necessary to evaluate non key muscle in every patient; it is appropriate to evaluate it in ABS B patients with motor function under injury level. No standard evaluation was defined for the muscle functions except the key muscles (8).

The ASIA International Standards Committee emphasized that this form was not perfect but enabled consistency (8).

To conclude, the use of the Turkish translation of the updated evaluation form of ISNCSCI, which is commonly used in the evaluation of patients with spinal cord injury, will provide a standard evaluation opportunity for our patients.
Author contributions: Concept - B.G., B.E.; Design - B.G., B.E.; Supervision - B.G., B.E.; Resource - B.G., B.E.; Materials - B.G., B.E.; Data Collection and/or Processing - B.G., B.E.; Analysis and/or Interpretation - B.G., B.E.; Literature Search - B.G., B.E.; Writing - B.G.; Critical Reviews - B.E.

Conflict of Interest: No conflict of interest was declared by the authors.

Financial Disclosure: The authors declared that this study has received no financial support.

\section{References}

1. Kirshblum SC, Biering-Sorensen F, Betz R, Burns S, Donovan W, Graves DE, et al. International Standards for Neurological Classification of Spinal Cord Injury: cases with classification challenges. J Spinal Cord Med 2014;37:120-7. [CrossRef]

2. Gündüz B. Medulla spinalis yaralanmalarında sınıflama. Türk Fizik Tip Rehab Derg 2002;48:12-4.

3. Kirshblum S, Burns S, Biering-Sorensen F, Donovan W, Graves D, Jha $A$, et al. International standards for neurological classification of spinal cord injury (Revised 2011). J Spinal Cord Medicine 2011;34:535-46. [CrossRef]

4. Kirshblum S, Waring W, Biering-Sorensen F, Burns S, Johansen M, Schmidt-Read M, et al. Reference for the 2011 revision of the International Standards for Neurological Classification of Spinal Cord Injury. J Spinal Cord Med 2011;34:547-54 [CrossRef]

5. Gündüz B, Erhan B. Omurilik Yaralanması Nörolojik Sınıflaması için Uluslararası Standartlar 2011 revizyonu: Değerlendirme Formu Türkçe çevirisi". Türk Fizik Tıp Rehab Derg 2012;58:42-45.

6. Erhan B, Gündüz B. Omurilik yaralanmalı hastanın muayenesi. Omurga ve Omurilik Yaralanmaları. In: Özer AF, Zileli M, editors. Antalya; Inter Tıp Kitapevi 2013. p. 1879-89.

7. American Spinal Injury Association: International Standards for Neurological Classification of Spinal Cord Injury, revised 2013; Atlanta, GA. Reprinted 2013.

8. The New Worksheet. Available from: http://www.asia-spinalinjury. org/elearning/Whats_new_with_INSCSCI-ASIA_072413_reduced. pdf. Accessed June 30, 2014. 